\title{
Occurrence of anti-Neospora caninum antibodies in dogs in rural areas in Minas Gerais, Brazil
}

\author{
Ocorrência de anticorpos anti-Neospora caninum em cães de áreas rurais em Minas Gerais, Brasil \\ Fábio Raphael Pascoti Bruhn ${ }^{1}$; Vânia Chaves Figueiredo${ }^{1}$; Gislaine da Silva Andrade ${ }^{1}$; Lívio Martins Costa-Júnior²; \\ Christiane Maria Barcellos Magalhães da Rocha ${ }^{1}$; Antônio Marcos Guimarães ${ }^{1 *}$ \\ ${ }^{1}$ Departamento de Medicina Veterinária, Universidade Federal de Lavras - UFLA, Lavras, MG, Brasil \\ ${ }^{2}$ Centro de Ciências Agrárias e Ambientais, Universidade Federal do Maranhão - UFMA, Chapadinha, MA, Brasil
}

Received July 1, 2011

Accepted October 10, 2011

\begin{abstract}
The aim of this study was to determine the frequency of anti-Neospora caninum antibodies and risk factors associated with seropositivity in 240 dogs from rural areas of the Lavras, Belo Horizonte and Nanuque regions, state of Minas Gerais, Brazil. The indirect fluorescence antibody test (IFAT) with a cutoff of 50 was used to assess the frequency of seropositive dogs. The risk factor analysis was performed using the Chi-square test $\left(\chi^{2}\right)$ and multiple logistic regression. The frequency of seropositivity for $N$. caninum was $15 \%$ of the dogs $(36 / 240)$. Presence of dogs without defined breed $(\mathrm{p}=0.018 ; \mathrm{OR}=5.9)$ and presence of cattle on the farm $(\mathrm{p}=0.053$, $\mathrm{OR}=4.3)$ were associated with $N$. caninum seropositivity. Dogs in the Nanuque region had higher seropositivity for $N$. caninum (29.9\%) than did those in the Lavras $(6.2 \%)$ and Belo Horizonte $(2.2 \%)$ regions $(\mathrm{p}<0.05)$. The presence of seropositive dogs in rural areas of Minas Gerais demonstrates the potential risk of horizontal transmission of $N$. caninum to cattle, especially from dogs without defined breed, which were four times more likely to be seropositive than purebred dogs were.
\end{abstract}

Keywords: Neospora caninum, dogs, Minas Gerais, risk factors, IFAT.

\section{Resumo}

O objetivo deste estudo foi determinar a frequência de anticorpos anti-Neospora caninum e fatores de risco associados à soropositividade, em 240 cáes de áreas rurais, nas regiôes de Lavras, Belo Horizonte e Nanuque, Minas Gerais, Brasil. Foi utilizada a reação de imunofluorescência indireta (RIFI), com um ponto de corte igual a 50, para avaliar a frequência de cáes soropositivos. A análise dos fatores de risco foi realizada pelo teste de Qui-quadrado $\left(\chi^{2}\right)$ e regressão logística múltipla. A frequência de cáes soropositivos para $N$. caninum foi de 15\% (36/240). A presença de cáes sem raça definida $(\mathrm{SRD})(\mathrm{p}=0,018 ; \mathrm{OR}=5,9)$ e bovinos na propriedade $(\mathrm{p}=0,053 ; \mathrm{OR}=4,3)$ foi associada à soropositividade pelo $N$. caninum. A frequência de cáes soropositivos foi mais elevada na região de Nanuque (29,9\%), quando comparados aos das regiôes de Lavras $(6,2 \%)$ e Belo Horizonte $(2,2 \%)(\mathrm{p}<0,05)$. A presença de cães soropositivos, em áreas rurais de Minas Gerais, demonstra o risco potencial da transmissão horizontal de $N$. caninum para os bovinos, especialmente os cães SRD, que apresentaram quatro vezes mais a chance de serem soropositivos em relação aos cães com raça definida.

Palavras-chave: Neospora caninum, cães, Minas Gerais, fatores de risco, RIFI.

Neosporosis is a disease caused by the protozoon Neospora caninum (Apicomplexa: Sarcocystidae) that may give rise to severe neuromuscular manifestations (DUBEY et al., 2007). Domestic dogs (Canis lupus familiaris) and wild dogs (C. lupus latrans, C. lupus dingo e C. lupus) can be considered to be the definitive hosts for $N$. caninum, and therefore they present a potential risk of transmission to herbivores. This parasite is an

\footnotetext{
*Corresponding author: Antônio Marcos Guimarães

Departamento de Medicina Veterinária, Universidade Federal de Lavras - UFLA, CP 3037, CEP 37200-000, Lavras, MG, Brasil

e-mail:amg@dmv.ufla.br
}

important cause of abortion among production animals, especially cattle (DUBEY; LINDSAY, 1996; McALLISTER et al., 1998; GONDIM et al., 2004; BJÖRKMAN et al., 2010; DUBEY et al., 2011).

Although infection due to $N$. caninum is widely distributed among cattle herds in Minas Gerais (GUEDES et al., 2008), studies on canine infection due to this protozoon in rural areas of this state are still scarce (FERNANDES et al., 2004). Thus, the main objective of the present study was to carry out a serologicalepidemiological study on this infection among dogs in rural areas of the state of Minas Gerais and to evaluate risk factors for this infection among these animals. 
The samples tested in this study formed part of a serum bank that had previously been used in other studies on blood parasites in dogs (COSTA-JÚNIOR et al., 2007; 2009). This serum bank was created between April and September 2004, from random collection of 240 blood samples from dogs reared on farms in six municipalities in three distinct regions of the state of Minas Gerais: region of Nanuque (97 dogs) - municipalities of Carlos Chagas and Umburatiba; region of Belo Horizonte ( 46 dogs) - municipality of Igarapé; and region of Lavras (97 dogs) - municipalities of Carrancas, Cruzília and São Vicente de Minas.

Antibodies in the serum samples were investigated by means of the indirect immunofluorescence antibody test (IFAT), using tachyzoites from $N$. caninum fixed on glass slides (Imunodot Laboratory, Jaboticabal, SP, Brazil) and canine anti-IgG conjugate (Sigma Chemical Co., St. Louis, Missouri, USA). Serum samples in which the tachyzoites presented fluorescence at a dilution of 1:50 were considered to be positive (DUBEY et al., 1988). At the time of blood sample collection, each dog was identified and the owner was interviewed with the aim of gathering information about the farm property: rearing of domestic poultry and/or cattle (without distinction between different breeds or the rearing methods used for these animals) and any presence of wild canids of any type, in contact with the domestic dogs, as well as individual data on the dogs analyzed (rearing methods, breed, sex, age and size).

Associations between seropositivity for $N$. caninum and the variables studied were evaluated by means of the Chi-square $\left(\chi^{2}\right)$ or Fisher exact test. The latter was used when the number of observations in at least one cell of the test was less than five. For the significant variables $(\mathrm{p}<0.05)$, odds ratios $(\mathrm{OR})$ were calculated with their $95 \%$ confidence intervals. Variables that presented $\mathrm{p}<0.20$ in the $\chi^{2}$ or Fisher exact test were selected for constructing the multiple model, by means of logistic regression, with the aim of ascertaining the adjusted odds ratios. For this, the dependent variable "seropositivity for $N$. caninum" was transformed into a dichotomous variable ( $0=$ negative; 1 = positive). All the analyses were performed using the PASW 18.0 statistical software.

Out of the 240 dog serum samples tested, 15\% (36) presented anti- $N$. caninum antibodies. This percentage was lower than what was reported by Fernandes et al. (2004) and Romanelli et al. (2007), respectively, among dogs in rural areas of Uberlândia, MG (21.7\%), and Guarapuava, PR (29\%); and it was higher than the rate observed by Aguiar et al. (2006) among dogs in rural areas of Monte Negro, Rondônia (12.6\%). Compared with urban dogs (GENNARI et al., 2002; GUIMARÁES et al., 2009), those from rural areas tend to present greater seropositivity for $N$. caninum, since they are at greater risk of exposure to the parasite, through ingestion of remains of placentas, aborted fetuses or intermediate hosts such as birds and small mammals (FERNANDES et al., 2004).

The frequencies of seropositive dogs in the Nanuque, Lavras and Belo Horizonte regions were 29.9\% (29/97), 6.2\% (6/97) and $2.2 \%(1 / 46)$, respectively. Dogs on farms in the Nanuque region presented a 19.2-times greater chance $(\mathrm{CI}=2.5-145.9$; $\mathrm{p}<0.01)$ of seropositivity for $N$. caninum than shown by the dogs in the Belo Horizonte region and a 6.5 times greater chance $(\mathrm{CI}=2.5-16.5 ; \mathrm{p}<0.01)$ than shown by the dogs in the Lavras region. In the Nanuque region, beef cattle farms with extensive rearing schemes and low levels of technification predominated, thus differing from the Lavras and Belo Horizonte regions, where dairy cattle predominated and there was better zoosanitary control over the herds. This is probably why the dogs on these farms were less infected by N. caninum. Aguiar et al. (2006) did not find any significant difference $(\mathrm{p}>0.05)$ between the type of farming practiced (dairy, beef or both) and the prevalence of dogs that were seropositive for $N$. caninum in cattle herds in the state of Rondônia. However, because of the large differences in cattle epidemiology and rearing in different regions of Brazil, caution is required in making this type of comparison.

Table 1 presents the results from univariate analysis on the variables and their associations with occurrences of anti- $N$. caninum antibodies. Among the variables tested, the presence of domestic poultry showed associations $(\mathrm{p}<0.05)$ with positivity for $N$. caninum (odds ratio $=3.4 ; 95 \% \mathrm{CI}=0.99-11.5$ ) and with the variable of no defined breed for the $\operatorname{dog}(\mathrm{p}<0.05)$ (odds ratio $=5.4 ; 95 \%$ $\mathrm{CI}=1.2-23.1$ ). The variables of no defined dog breed, presence of poultry and presence of cattle were included in the multiple logistic regression model, and no defined $\operatorname{dog}$ breed $(\mathrm{p}=0.018 ; \mathrm{OR}=5.9)$ and presence of cattle on the farm $(\mathrm{p}=0.053$; $\mathrm{OR}=4.3)$ remained statistically significant in the final model. Cunha Filho et al. (2008) did not find any association ( $p>0.05$ ) between breed and positivity for $N$. caninum among dogs in rural areas of Pelotas, state of Rio Grande do Sul.

In the present study, it was found that $21 \%$ of the dogs belonged to defined breeds (50/240), and Pinscher (60.4\%) and Fila Brasileiro (10.4\%) were the commonest breeds. The results indicate that in the areas studied, dogs of no defined breed constituted a risk factor for infection by $N$. caninum, since these dogs presented a chance of being seropositive that was almost six times greater than shown by dogs of defined breeds.

The variable of presence of domestic poultry was not significant in the final multiple logistic regression model because of its association with the factor of dog breed, which was seen univariate analysis using the $\chi^{2}$ test $(\mathrm{p}<0.046)$. Hence, the presence of poultry was a confounding variable that was more associated with the presence of dogs of no defined breed than with positivity for $N$. caninum. It is likely that these two variables would characterize smallholdings or family producers, where stray dogs would have easier access and would have a greater possibility of living together with reared hens, which they might eat because of the carnivorous and hunting habits inherent to domestic dogs. Domestic poultry may act as intermediate hosts for $N$. caninum (COSTA et al., 2008; MARTINS et al., 2011) and can easily become infected through their habit of frequently pecking at the ground where they live, thus ingesting sporulated oocysts of this coccid. It is possible that dogs become infected through ingesting tissue from these birds that are infected with the parasite (HEMPHILL; GOTTSTEIN, 2000). However, further studies are needed in order to define the intensity of this association.

The presence of cattle on farms, which did not present any significant association ( $p>0.05$ ) with the frequency of dogs that were seropositive for $N$. caninum in the univariate model, started to have an association in the multiple model. This was probably because the presence of dogs with no defined breed was related more to the stray habits of these animals, in which they might invade other farms and feed on reproductive material from cattle 
Table 1. Occurrences of anti-Neospora caninum antibodies (IFAT $\geq 1: 50$ ), according to the variables analyzed, among dogs from rural areas in the Belo Horizonte, Lavras and Nanuque regions, state of Minas Gerais, Brazil, 2004.

\begin{tabular}{|c|c|c|c|c|c|c|}
\hline \multicolumn{2}{|c|}{ Variables } & \multicolumn{3}{|c|}{ No. of dogs } & \multirow[t]{2}{*}{ p value ${ }^{1}$} & \multirow[t]{2}{*}{$\mathbf{O R}^{2}$} \\
\hline & & $\mathbf{N}$ & + & $\%$ & & \\
\hline \multirow{2}{*}{ Presence of domestic poultry } & Yes & 189 & 33 & 17.5 & 0.046 & 3.4 \\
\hline & No & 51 & 3 & 5.9 & & $(0.99-11.5)$ \\
\hline \multirow{2}{*}{ Presence of cattle } & Yes & 201 & 34 & 16.9 & 0.083 & - \\
\hline & No & 39 & 2 & 5.1 & & \\
\hline \multirow{2}{*}{ Contact between dogs and wild canids } & Yes & 69 & 8 & 11.6 & 0.348 & - \\
\hline & No & 171 & 28 & 16.4 & & \\
\hline \multirow{2}{*}{ Dog rearing method } & Unconfined & 225 & 35 & 15.6 & 0.706 & - \\
\hline & Confined & 15 & 1 & 6.7 & & \\
\hline \multirow{2}{*}{ Defined breed } & Yes & 51 & 2 & 3.9 & 0.013 & 5.4 \\
\hline & No & 189 & 34 & 18.0 & & $(1.2-23.1)$ \\
\hline \multirow{2}{*}{ Sex } & Male & 175 & 29 & 16.6 & 0.263 & - \\
\hline & Female & 65 & 7 & 10.8 & & \\
\hline \multirow{2}{*}{ Age } & $\leq 2$ years & 119 & 16 & 13.4 & 0.504 & - \\
\hline & $>2$ years & 121 & 20 & 16.5 & & \\
\hline \multirow{2}{*}{ Size } & Small/medium & 176 & 27 & 15.3 & 0.806 & - \\
\hline & Large & 64 & 9 & 14.1 & & \\
\hline \multirow{3}{*}{ Region } & Belo Horizonte & 46 & 1 & 2.2 & - & 1 \\
\hline & Lavras $^{3}$ & 97 & 6 & 6.2 & 0.429 & - \\
\hline & Nanuque $^{3}$ & 97 & 29 & 29.9 & 0.001 & $\begin{array}{c}19.2 \\
(2.5-145.9)\end{array}$ \\
\hline
\end{tabular}

${ }^{1}$ Chi-square test; ${ }^{2} \mathrm{Odds}$ ratio (OR) with $95 \%$ confidence interval; $\mathrm{N}=$ number of dogs analyzed; $+=$ number of positive dogs; ${ }^{3} \mathrm{P}$ $95 \% \mathrm{CI}=2.5-16.5)$.

(placental remains and/or aborted fetuses) on neighboring farms. In other words, dogs of no defined breed could become infected with $N$. caninum, independent of the presence of cattle on the farm where they were in fact reared. This would diminish the effect of the presence of cattle on farms where dogs were diagnosed as seropositive for $N$. caninum. However, after adjustment of the odds ratio by means of the multiple model, "presence of cattle on the farm" became significant, thereby showing that independent of the "presence of dogs of no defined breed" (i.e. probably strays), places where cattle rearing took place presented a higher chance of having dogs infected with $N$. caninum.

The presence of seropositive dogs in rural areas of the state of Minas Gerais demonstrates the potential risk of horizontal transmission of $N$. caninum to cattle reared on farms in the Lavras, Belo Horizonte and Nanuque regions.

\section{Acknowledgements}

To the Research Support Foundation of the State of Minas Gerais (Fundação de Apoio à Pesquisa do Estado de Minas Gerais, FAPEMIG - no. CVZ APQ-7963-5.04/07) for financial support.

\section{References}

Aguiar DM, Cavalcante GT, Rodrigues AAR, Labruna MB, Camargo LMA, Camargo EP, et al. Prevalence of anti-Neospora caninum antibodies in cattle and dogs from Western Amazon, Brazil, in association with some possible risk factors. Vet Parasitol 2006; 142(1-2): 71-77. PMid:16857319. http://dx.doi.org/10.1016/j.vetpar.2006.06.014
Björkman C, Jakubek EB, Arnemo JM, Malmsten J. Seroprevalence of Neospora caninum in gray wolves in Scandinavia. Vet Parasitol 2010; 173(1-2): 139-142. PMid:20609524. http://dx.doi.org/10.1016/j. vetpar.2010.06.006

Costa KS, Santos SL, Uzêda RS, Pinheiro AM, Almeida MAO, Araújo FR, et al. Chickens (Gallus domesticus) are natural intermediate hosts of Neospora caninum. Int J Parasitol 2008; 38(2): 157-159. PMid:18054356. http://dx.doi.org/10.1016/j.ijpara.2007.10.008

Costa-Júnior LM, Rembeck K, Ribeiro MFB, Beelitz P, Pfister K, Passos LMF. Sero-prevalence and risk indicators for canine ehrlichiosis in three rural areas of Brazil. Vet J 2007; 174(3): 673-676. PMid:17204439. http://dx.doi.org/10.1016/j.tvjl.2006.11.002

Costa-Júnior LM, Ribeiro MFB, Rembeck K, Rabelo EML, Zahler-Rinder M, Hirzmann J, et al. Canine babesiosis caused by Babesia canis vogeli in rural areas of the State of Minas Gerais, Brazil and factors associated with its seroprevalence. Res Vet Sci 2009; 86(2): 257-260. PMid:18723199. http://dx.doi.org/10.1016/j.rvsc.2008.07.002

Cunha Filho NA, Lucas AS, Pappen FG, Ragozo AMA, Gennari $\mathrm{Sm}$, Lucia Júnior T, et al. Fatores de risco e prevalência de anticorpos anti-Neospora caninum em cães urbanos e rurais do Rio Grande do Sul, Brasil. Rev Bras Parasitol Vet 2008; 17(1): 301-306. PMid:20059865.

Dubey JP, Jenkins MC, Rajendran C, Miska K, Ferreira LR, Martins J, et al. Gray wolf (Canis lupus) is a natural definitive host for Neospora caninum. Vet Parasitol 2011; 181(2-4): 382-387. PMid:21640485. http://dx.doi. org/10.1016/j.vetpar.2011.05.018

Dubey JP, Carpenter JL, Speer CA, Tooper MJ, Uggla A. Newly recognized protozoan disease of dogs. J Am Vet Med Assoc 1988; 192(9): 1269-1285. PMid:3391851. 
Dubey JP, Vianna MC, Kwok OC, Hill DE, Miska KB, Tuo W, et al. Neosporosis in Beagle dogs: Clinical signs, diagnosis, treatment, isolation and genetic characterization of Neospora caninum. Vet Parasitol 2007; 149(3-4): 158-166. PMid:17890012. http://dx.doi.org/10.1016/j. vetpar.2007.08.013

Dubey JP, Lindsay DS. A review of Neospora caninum and neosporosis. Vet Parasitol 1996; 67(1-2): 1-59. http://dx.doi.org/10.1016/ S0304-4017(96)01035-7

Fernandes BCTM, Gennari SM, Souza SLP, Carvalho JM, Oliveira WG, Cury MC. Prevalence of anti-Neospora caninum antibodies in dogs from urban, periurban and rural areas of the city of Uberlândia, Minas Gerais-Brazil. Vet Parasitol 2004; 123(1-2): 33-40. PMid:15265569. http://dx.doi.org/10.1016/j.vetpar.2004.05.016

Gennari SM, Yai LEO, D’Áuria SNR, Cardoso SMS, Kwok OCH, Jenkins MC, et. al. Occurrence of Neospora caninum antibodies in sera from dogs of the city of São Paulo, Brazil. Vet Parasitol 2002; 106(2): 177-179. http://dx.doi.org/10.1016/S0304-4017(02)00052-3

Gondim LFP, McAllister MM, Pitt WC, Zemlicka DE. Coyotes (Canis latrans) are definitive hosts of Neospora caninum. Int J Parasitol 2004; 34(2): 159-161. PMid:15037103. http://dx.doi.org/10.1016/j. ijpara.2004.01.001

Guedes MHP, Guimarães AM, Rocha CMBM, Hirsch C. Frequência de anticorpos anti-Neospora caninum em vacas e fetos provenientes de municípios do sul de Minas Gerais. Rev Bras Parasitol Vet 2008; 17(4): 189-194. PMid:19265576.
Guimarães AM, Rocha CMBM, Oliveira TMFS, Rosado IR, Morais LG, Santos RRD. Fatores associados à soropositividade para Babesia, Toxoplasma, Neospora e Leishmania em cães atendidos em nove clínicas veterinárias do município de Lavras, MG. Rev Bras Parasitol Vet 2009; 18(Suplem. 1): 49-53.

Hemphill J, Gottstein B. A European perspective on Neospora caninum. Int J Parasitol 2000; 30(8): 877-924. http://dx.doi.org/10.1016/ S0020-7519(00)00072-2

Martins J, Kwok OCH, Dubey JP. Seroprevalence of Neospora caninum in free-range chickens (Gallus domesticus) from the Americas. Vet Parasitol 2011; 182(2-4): 349-351. PMid:21676546. http://dx.doi. org/10.1016/j.vetpar.2011.05.023

McAllister MM, Dubey JP, Lindsay DS, Jolley WR, Wills RA, McGuire AM. Dogs are definitive hosts of Neospora caninum. Int J Parasitol 1998; 28(9): 1473-1478. http://dx.doi.org/10.1016/S0020-7519(98)00138-6

Romanelli PR, Freire RL, Vidotto O, Marana ERM, Ogawa L, De Paula VSO, et al. Prevalence of Neospora caninum and Toxoplasma gondii in sheep and dogs from Guarapuava farms, Paraná State, Brazil. Res Vet Sci 2007; 82(2): 202-207. PMid:17266999. http://dx.doi.org/10.1016/j. rvsc.2006.04.001 